\title{
Methodology Formulation for Exact Location Tracking of Node Positions in Ubicomp MANETs Using NS2.
}

\author{
M. Kaleem GALAMALI, Assoc. Prof Nawaz MOHAMUDALLY
}

\begin{abstract}
The need for reliability in the field of ubicomp is well recognised [1] so as to make business and day-today running of ubicomp dependable. Along with ubicomp progresses, several reliability related questions will also crop up and quite some research has been based on empirical simulator based approaches to supply answers [14-65] and new metrics for ubicomp have been laid forward. What now must be put forward in research community is the methodology that was devised so that the previous work [14-65] could be carried out. The methodology itself has been novel and required designing and implementing components that were not previously developed nor was available off-the-shelf. The methodology is split into five steps.
\end{abstract}

In this paper, the first step concerning methodology of gathering the exact location of positions and its particularities are put forward. This is carried out irrespective of concerns for whether MANET nodes are supplied as infrastructure or not.

The results of this study can serve towards better formulation of "Exact Location Tracking of Ubicomp MANET nodes" or using this methodology devised to prepare many off-the-shelf such components over various movement patterns in ubicomp. This would in turn, facilitate work of further research in the research community. This paper is a retrospective delivery of the methodology developed over which previous work [14-65] was done.

Key terms: Ubicomp- Ubiquitous Computing, CBR- Constant Bit Rate, MANET- Mobile Adhoc Network, NS2- Network Simulator 2.

M. Kaleem GALAMALI,

University of Technology Mauritius (student) Mauritius

Assoc. Prof Nawaz Mohamudally University of Technology Mauritius, Mauritius

\section{Introduction}

The knowledge of trends of metrics for energy consumption and distance coverages by transmission packets together with fairness related metrics may prove crucial for future ubicomp architecture designs [14-65]. It is also important to know the methodology developed to enable such experimental studies. This methodology was split into 5 components to be devised and are as follows: i. Tracking of exact positions of ubicomp MANET nodes.

ii. MANET Route formulation and tracking nodes energy expenditure.

iii. Processing of MANET_Routes_Packets_Per_CBR

iv. MANET Results Generations.

v. Automated Extraction of Data From Files

The prior work performed [14-65] were all based on application of exact location-awareness at per packet transmission level. The aspects of location-awareness concerns updating information on nodes positions at good enough refresh rates. In actual implementations, the granularity or exactness of this location information varies as per technology used, which however experience extraneously high overheads to obtain high refresh rates. This further impacts on energy needs and levels of noise present in the topography. Hence simulation based studies serve as good starting points.

The basis of all previous work [14-65] has lied in the ability to track exact positions at very small snapshots of time. The key contribution of this paper is the elaboration of a method for developing one of the five components, together with its design peculiarities, over which previously reported empirical studies [14-65] were carried out. The component here concerns tracking of exact positions of ubicomp MANET nodes in a simulator environment over a topography of $300 \mathrm{x}$ $300 \mathrm{~m}^{2}$. The rest of this paper is organised as follows: section 2: Experimental set-up used, section 3: Methodology Details and Section 4: Conclusion and References.

\section{Experimental Set-Up Used.}

The experimental platform used has been as follows:

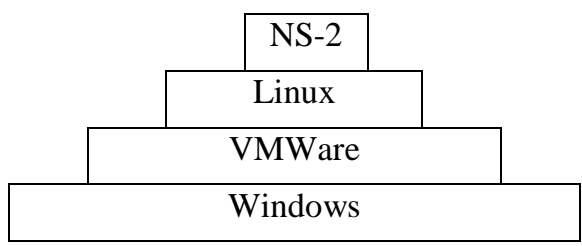

Figure 1: Layout of NS2 over Linux on VMWare. Network Simulator 2 (NS2) was chosen for this study for the advantages it offers and its limitations are not consequential to this study. It is also open-source, i.e. no cost of purchase. Additional characteristics of NS2 can be studied at another paper [66]. NS2 gives possibility of exact location tracking up to 12 decimal 
places of a meter, and also the possibility of collecting information regularly at very small intervals of time. The programming language used is TCL.

The most popular virtual machine is VMWare Workstation and version 7.1.3 was obtained and installed easily (just click next). VMWare workstation is an advanced software with a comprehensive graphical user interface with a help feature available. The very interesting thing, is that it is not necessary to learn all its features before using it; just enough to operate what is needed, and the work can be done.

CentOS Linux version 6 was installed in VMWare. CentOS on VMWare requires 2 GB main memory and rapid processor speeds.

Delays are noticed only when CentOS is powered on in VMWare. Normal operations did not seem affected by much delays.

\section{Methodology Details.}

\subsection{Component Re-Use from Previous Work.}

Many Components devised previously have been reused. These include the 60 movement scenario files using pre-established and reproducible movement scenarios described in sections 2.4 and 2.6 of a previous paper [2], the main program where NS new simulator is declared as referred to in the whole of section 2 of previous paper [2]. The simulation runs were done on new filenames and additional codes for tracking have been devised and incorporated.

\subsection{Node Densities for Simulations to Run.}

Ideally there was need to run simulations for 7 nodes, 8 nodes, incrementally up-to 60 nodes each over 60 movement patterns. These would have made 3600 experiments. This would have represented really big amount of work and very time-consuming. A closer study of the initial positioning for 7 nodes, 8 nodes and 9 nodes is made. Their initial positions is depicted pictorially within topography as illustrated in Figure 2:

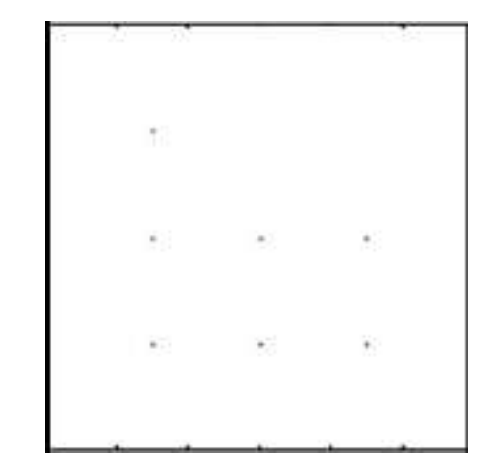

Figure 2a: 7-nodes initial positions

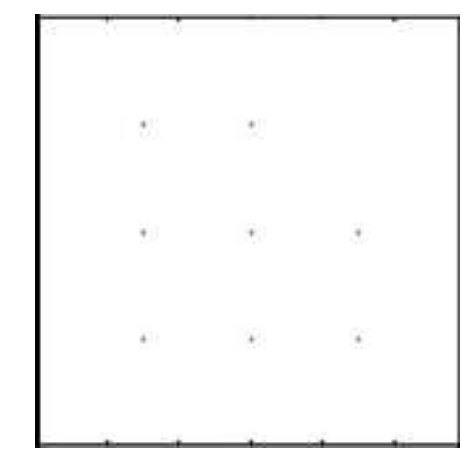

Figure 2b: 8-nodes initial positions

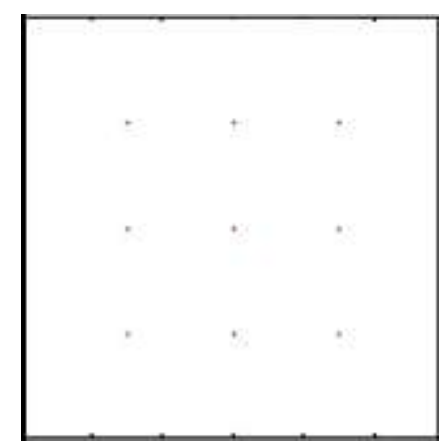

Figure 2c: 9-nodes initial positions

It can be noticed that the 7-nodes is repeated in the 8nodes scenario which is in turn repeated in the 9-nodes scenario. The movement scenario files are consistent over 60 nodes within one movement file. Hence the output -positions for 7-nodes would be repeated in the output-positions for 8-nodes which in turn would be repeated in the 9-node output-position file. Therefore, there is no need to carry out simulations over the 7 and 8-nodes scenarios, since these can be extracted from the 9-node simulation output-positions files.

More generally, we recall that uniform positionings of nodes is used whereby number of nodes takes the form of $n^{2}$ or $n(n-1)$. Hence starting with 7 nodes until 60 nodes, 11 sets of experiments is being identified. This is illustrated in Table 1.

\begin{tabular}{|c|c|c|}
\hline Experiment Set & Number of nodes & $\mathbf{n}^{2}$ or $\mathbf{n}(\mathbf{n}-1)$ \\
\hline 1 & $7-9$ & $3 \times 3=9$ \\
\hline 2 & $10-12$ & $4 \times 3=12$ \\
\hline 3 & $13-16$ & $4 \times 4=16$ \\
\hline 4 & $17-20$ & $5 \times 4=20$ \\
\hline 5 & $21-25$ & $5 \times 5=25$ \\
\hline 6 & $26-30$ & $5 \times 6=30$ \\
\hline 7 & $31-36$ & $6 \times 6=36$ \\
\hline 8 & $37-42$ & $7 \times 6=42$ \\
\hline 9 & $43-49$ & $7 \times 7=49$ \\
\hline 10 & $50-56$ & $8 \times 7=56$ \\
\hline 11 & $57-60$ & $8 \times 8=64$ \\
\hline
\end{tabular}

Table 1: Experiment sets identified for positions tracks.

Each set of simulation has been run over 60 movement scenarios, totalling $660(11 \times 60)$ simulations in all. It is still quite big amount of work but remains hopefully workable. 


\subsection{Design Issues -Time Interval For Location Refresh.}

The bigger the interval to be used, the lesser the number of location tracks recorded, the lesser the amount of workable data and more importantly the bigger the amount of tolerance ranges that would be needed to incorporate for later processing. The effects of the other extreme, i.e. too small interval is obvious: much data will be generated consuming lots of storage space. A proper balance is of course needed. Packet transmission timings used are up to $60 \mathrm{~m} / \mathrm{s}$. Packet delay is a factor of $0.001 \mathrm{sec}$ and between $1 \mathrm{~ms}$ and 10 ms. It is hence the strong ground for selecting $0.001 \mathrm{~s}$ $(1 \mathrm{~ms})$ as interval for refreshing information about location of nodes in an experiment.

$1 \mathrm{~ms}$ as location refresh interval, would imply a tolerance of $0.06 \mathrm{~m}(6 \mathrm{~cm})$. When squared for processing, it will lead to a tolerance of $\left(3.6 \times 10^{-4}\right) \mathrm{m}^{2}$. Hence tolerance/uncertainties will be very insignificant.

An experiment which will last for 250 seconds will perform 250001 equally intervalled location trackings. It is pointed out that this is feasible in a simulator environment and lots of data generation is expected.

\subsection{Making Same Program Work For Varying Node}

\section{Densities.}

The simulation program has to work for 11 sets of node densities identified in section 3.1 above. Several design strategies were pondered over like having 11 sets of "if" statements to accommodate processing, accompanied by 11 different sub-programs whereby each subprogram will have a number of parameters corresponding to the number of nodes and time at which location track is performed. Programming would have been quite lengthy. The problem was solved by designing one sub-program consisting of 62 parameters: the time of tracking, the number of nodes concerned and the maximum of 60 parameters reserved for nodes. A component for appending the names of valid nodes (separated by a space) and a component for appending " 0 " for non-valid nodes (again separated by a space) have been devised and saved on a different page; it contains about 60 "if statements to check existence of each node by its index before continuing to process, to accommodate for the maximum of 60 possible nodes. The processing is similar for any number of nodes to be used.

Using 62 parameters does expand program execution onto memory and take some more time. More execution time has been observed for larger numbers of node densities. But these do not seem to have been of consequent impacts on the simulation runs since subprogram calling is done in loops and memory is freed once a loop is completed. Overall they have worked well.

\subsection{Functionality of Experiment Runs.}

The main program where "NS [new Simulator]" is declared takes in number of nodes (opt(nn)), undertake their uniform initial positioning and extract movement patterns from the appropriate movement file. A file for tracking locations has been created for appending and has name-format "filename('movement_num', 'node_num')". A sub-program for collecting and saving location information pertaining to each node is called every $0.001 \mathrm{~s}$. The information will be in the form of records/lines in the following format:

“track_time 'time' node 'node_num' $x$ : 'x_coord' $y$ : 'y_coord' z: 'z_coord' "

Part A consist of the part track_time 'time', i.e. the word track time and value of the time. Part B constitute the remaining part of the line.

Part B is replicated and appended to the line for successive nodes declared in ascending order of their node indexes.

\subsection{Experiments Duration and Data Generation Rates}

One experiment out of the 660 identified over 1 laptop lasts about 15 to 20 minutes, generating about 300 $\mathrm{KBps}$ of data. Use of 2-3 laptops simultaneously is expected to help in.

Certain abnormal behaviours have also been noticed. Certain experiments were taking about 5 hours to complete. It was later noticed that it was generating 4 KBps of data only. The possible reasons for this misbehaviour can be very vast: it can be due to some unoptimised components within NS2 or that the program execution has expanded into virtual memory and the component for managing which parts to evict from virtual memory and bring in main memory is not correct. It's an interesting subject of investigation but outside the scope of this present research investigation, especially since a way to bypass it has been found.

The solution adapted to such a problematic experiment has been to split the experiment into two: one for duration $0.000 \mathrm{sec}$ until $125.000 \mathrm{sec}$ and one for duration $125.001 \mathrm{sec}$ until $250.000 \mathrm{sec}$. Such a solution has worked since the $300 \mathrm{KBps}$ data generation is observed. The second time running continues appending data into the file generated by the first time running. Another trade-off is the optimisation attempt described in section 3.7 may not apply for track times $125.000 \mathrm{sec}$ and $125.001 \mathrm{sec}$. This represents only one 
additional record and hence is of very low impact. This solution has been applied to about 105 simulations and the consequence of time savings is obvious.

Experiments for smaller number of nodes tend to take lesser time than those involving more nodes. This may be so since more nodes imply more processing. Also, experiment splitting occurred in all experiment sets identified but was more frequent for larger number of nodes.

\subsection{Trend For Storage Requirements/Need for}

\section{Optimisation.}

This study was carried out during the initial experiment runs studying a track file, it was observed that several records were having same data (except for track time). For example 505 records representing track times starting from $0.000 \mathrm{sec}$ until $0.504 \mathrm{sec}$ were having same location track information. This is so because during the experiment runs, effective movement starts as from slightly above 0.504 seconds. This represents a serious redundancy problem since overall in 1 run, 250 001 record is gathered per experiment. The need for optimising is felt necessary here.

The solution is implemented as follows: starting from the very first record, the location information in next record generated is counterchecked with previous record. If it is similar it is not saved and if it is different it is saved into hard disk. Effectively each new record represents a consequent change in location information.

The progress reached with this solution is that average number of records revolved around 96000 to 98000 , representing above $60 \%$ of savings of hard disk space. This is deemed good progress.

Possibility of further optimisations is not excluded. Words "node" and "track_time" could be substituted with the words " $n$ " and "t_t" or simply be removed. This will impact seriously on considerable decrease in storage requirements. The resulting situation would represent some level of difficulty for understanding and debugging if the file is viewed at later stages.

Another optimisation possibility exists: from one record to the next, store information only for those nodes where changes in information have occurred. This remains complicated for programming and later retrieval of records for information processing needs.

For the purpose of this research investigation, investing hard disk space has been adopted with a view to facilitate later programming.

\subsection{Major NS2 Simulator Bug.}

A very consequent number of simulation runs were ending abruptly with message "Segmentation fault". This problem tended to be more acute with greater node densities and also that many simulations were stopping very early (30 sec, $62 \mathrm{sec}$ etc) and hence results generated would have been unworkable. The solution is provided by Carnegie Mellon University (CMU) and is illustrated by Arun Gupta in his blog [67]. The problem is experienced with routing protocol in conjunction with type of Queue being used. I used Direct Source

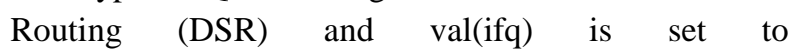
"Queue/Droptail/PriQueue". Arun Gupta puts forward that if DSR is to be used, val(ifq) must be set to "CMUPriQueue". This solution does not work for other routing protocols.

This solution has worked and at the point in time where it was confirmed, successive simulations were continued using this solution.

\subsection{Overall Time Taken.}

Each simulation has taken an average of 20 minutes. In one way, it has been an advantage since it allowed for certain parallel activities of programming also. It should be noted that successive simulations could not be carried out in loops, since only one instance of "NS new Simulator" can be launched when command "ns filename" is entered in Terminal of Linux. Hence the experiments could not be carried out continuously as in a loop. This set of experiments required roughly one month.

\subsection{Overall Storage Requirements.}

60 simulations were carried out in each of the 11 sets of experiments identified. The summary of information pertaining to file sizes is Table 2 whereby Column headings are: C1: Node Number, C2: Range of individual file sizes (MB), C3: Experiment set sub-total storage size (GB).

\begin{tabular}{|c|c|c|}
\hline C1 & C2 & C3 \\
\hline 9 & $43.8-51.2$ & 2.92 \\
\hline 12 & $59.8-67.6$ & 3.85 \\
\hline 16 & $82.1-89.2$ & 5.11 \\
\hline 20 & $102-111$ & 6.38 \\
\hline 25 & $129-139$ & 7.96 \\
\hline 30 & $157-166$ & 9.54 \\
\hline 36 & $191-198$ & 11.4 \\
\hline 42 & $221-232$ & 13.3 \\
\hline 49 & $259-270$ & 15.6 \\
\hline 56 & $297-309$ & 17.8 \\
\hline 60 & $318-331$ & 19.1 \\
\hline Total Space Needed: & 113 \\
\hline
\end{tabular}

\section{Table 2: Summary of file sizes for location tracks}

Since each set involved varying number of nodes, the individual file sizes across the set of ascending node densities, also is in ascending order. Also due to the 
optimisation attempt described in section 3.7, number of records in each file and corresponding file sizes within an experiment set varies (though lesser significantly).

\section{Conclusion.}

This piece of study has elaborated, with fine granule details, the formulation of a methodology and implementation of a method for tracking exact location tracking of node positions in ubicomp MANETs in NS2 simulator to a maximum of 12 decimal places of a metric. Such a methodology with modifications/refinements may be used by other researchers embarking on empirical research in ubicomp. This methodology has been novel and such components were not pre-existing. This methodology has been one of five components formulations over which empirical research [14-65] could be developed; this study however, remains a complete set in itself.

This methodology has been devised and implemented irrespective of concerns for MANET nodes being supplied as infrastructure or not. The results of this study can serve towards better formulation of "Exact Location Tracking of Ubicomp MANET nodes" or to use this methodology, with or without modifications, to prepare many off-the-shelf such components or to generate library files over various movement patterns in ubicomp for NS2. This would successively facilitate work of further research by other researchers.

Further work identified remains developing the methodology for the remaining four components identified in section 1 of this paper.

\section{References}

[1] M. Kaleem GALAMALI, Assoc. Prof Nawaz MOHAMUDALLY, Towards Dependable Pervasive Systems-A Position and Vision Paper, CEET 2014

[2] M. Kaleem GALAMALI, Assoc. Prof Nawaz MOHAMUDALLY, Model of Energy Savings achievable with Location-aware Node-to-Node Transmission in UbiComp, CEET 2014

[3] M. Kaleem GALAMALI, Assoc. Prof Nawaz MOHAMUDALLY, Model of Energy Savings achievable with Location-aware Node-to-Node Transmission in UbiComp Using Location Refresh Intervals, CEET 2014

[4] M. Kaleem GALAMALI, Assoc. Prof Nawaz MOHAMUDALLY, Model of Energy Savings achievable with Location-aware Transmission in UbiComp Using Relays, CEET 2014

[5] M. Kaleem GALAMALI, Assoc. Prof Nawaz MOHAMUDALLY, Mathematical modeling of need of exact number of relays to ensure seamless mobility in mobile computing, CEET 2014

[6] M. Kaleem GALAMALI, Assoc. Prof Nawaz MOHAMUDALLY, Modelling of need for multiple relays for ensuring seamless mobility, CEET 2014

[7] M. Kaleem GALAMALI, Assoc. Prof Nawaz
MOHAMUDALLY, Investigation of prominence of placements of relays in a ubicomp topography,

[8] M. Kaleem GALAMALI, Assoc. Prof Nawaz MOHAMUDALLY, Model of energy savings achievable with location-aware transmission in ubicomp using optimised number of relays.

[9] M. Kaleem GALAMALI, Assoc. Prof Nawaz MOHAMUDALLY, Investigation of Prominence of Placements of Optimised Number of Relays in a Ubicomp Topography using Location-Aware Transmission, CEET 2015.

[10] M. Kaleem GALAMALI, Assoc. Prof Nawaz MOHAMUDALLY, Extending Node Battery Availability in Ubicomp with Location-Aware Transmission, CEET 2015.

[11] M. Kaleem GALAMALI, Assoc. Prof Nawaz MOHAMUDALLY, Extending Node Battery Availability in Ubicomp with Location-Aware Transmission using Location Refresh Intervals, CEET 2015.

[12] M. Kaleem GALAMALI, Assoc. Prof Nawaz MOHAMUDALLY, Extending Node Battery Availability in Ubicomp with Location-Aware Transmission using Uniformly Placed Relays, CEET 2015.

[13] M. Kaleem GALAMALI, Assoc. Prof Nawaz MOHAMUDALLY, Extending Node Battery Availability in Ubicomp with Location-Aware Transmission Using Optimally Placed Relays, CEET 2015.

[14] M. Kaleem GALAMALI, Assoc. Prof Nawaz MOHAMUDALLY, Model of Sender Node Energy Savings Achievable with Location-Aware MANET Transmission in Ubicomp. ACCN 2016

[15] M. Kaleem GALAMALI, Assoc. Prof Nawaz MOHAMUDALLY, Model of Overall Node Energy Savings Achievable with Location-Aware MANET Transmission in Ubicomp. ACCN 2016

[16] M. Kaleem GALAMALI, Assoc. Prof Nawaz MOHAMUDALLY, Model of Sender Node Extra Energy Savings Achievable in MANET Against Direct Node-to-Node Transmission Using Location-Aware Transmission in Ubicomp. ACCN 2016

[17] M. Kaleem GALAMALI, Assoc. Prof Nawaz MOHAMUDALLY, Model of Overall Node Extra Energy Savings Achievable in MANET against Direct Node-to-Node Transmission Using Location-Aware Transmission in Ubicomp. ACCN 2016

[18] M. Kaleem GALAMALI, Assoc. Prof Nawaz MOHAMUDALLY, Model of Energy Consumption Ratio Achievable in MANET Using Location-Aware Transmission in Ubicomp. ACCN 2016

[19] M. Kaleem GALAMALI, Assoc. Prof Nawaz MOHAMUDALLY, Model of Minimum Energy Consumption Ratio Achievable in MANET Using LocationAware Transmission in Ubicomp. ACCN 2016

[20] M. Kaleem GALAMALI, Assoc. Prof Nawaz MOHAMUDALLY, Model of Maximum Energy Consumption Ratio Achievable in MANET Using LocationAware Transmission in Ubicomp. ACCN 2016

[21] M. Kaleem GALAMALI, Assoc. Prof Nawaz MOHAMUDALLY, Model of Overall Energy Consumption Fairness Ratio Achievable in MANET Using Location-Aware Transmission in Ubicomp. ACCN 2016

[22] M. Kaleem GALAMALI, Assoc. Prof Nawaz MOHAMUDALLY, Model of Overall Energy Consumption Fairness Proportion Achievable in MANET Using LocationAware Transmission for Ubicomp, CEET 2016

[23] M. Kaleem GALAMALI, Assoc. Prof Nawaz MOHAMUDALLY, Model of Minimum Fairness Proportion Achievable in MANET Using Location-Aware Transmission for Ubicomp, CEET 2016

[24] M. Kaleem GALAMALI, Assoc. Prof Nawaz MOHAMUDALLY, Model of Maximum Fairness Proportion Achievable in MANET Using Location-Aware Transmission for Ubicomp, CEET 2016

[25] M. Kaleem GALAMALI, Assoc. Prof Nawaz MOHAMUDALLY, Model of Sender Fairness Proportion Achievable in MANET Using Location-Aware Transmission for Ubicomp, CEET 2016

[26] M. Kaleem GALAMALI, Assoc. Prof Nawaz MOHAMUDALLY, Model of Distance Travelled by packets in MANETs using Location-Aware Transmission for Ubicomp, CEET 2016 
[27] M. Kaleem GALAMALI, Assoc. Prof Nawaz MOHAMUDALLY, Model of Maximum CBR Distance Travelled by packets in MANETs using Location-Aware Transmission for Ubicomp, CEET 2016

[28] M. Kaleem GALAMALI, Assoc. Prof Nawaz MOHAMUDALLY, Model of Minimum CBR Distance Travelled by packets in MANETs using Location-Aware Transmission for Ubicomp, CEET 2016

[29] M. Kaleem GALAMALI, Assoc. Prof Nawaz MOHAMUDALLY, Model of Range CBR Distance Experienced by Transmissions in MANETs using LocationAware Transmission for Ubicomp, CEET 2016

[30] M. Kaleem GALAMALI, Assoc. Prof Nawaz MOHAMUDALLY, Trend Analyses of Parameters of Equations for Sender Node Energy Savings Achievable in ubicomp MANETs using Location-Aware Transmission, ACCN 2017.

[31] M. Kaleem GALAMALI, Assoc. Prof Nawaz MOHAMUDALLY, Trend Analyses of Parameters of Equations for Overall Node Energy Savings Achievable in ubicomp MANETs using Location-Aware Transmission, ACCN 2017.

[32] M. Kaleem GALAMALI, Assoc. Prof Nawaz MOHAMUDALLY, Trend Analyses of Parameters of Equations for Sender Node Extra Energy Savings Achievable in MANET against Direct Node-to-Node Location-Aware Transmission, ACCN 2017.

[33] M. Kaleem GALAMALI, Assoc. Prof Nawaz MOHAMUDALLY, Trend Analyses of Parameters of Equations for Overall Nodes Extra Energy Savings Achievable in MANET against Direct Node-to-Node Location-Aware Transmission, ACCN 2017.

[34] M. Kaleem GALAMALI, Assoc. Prof Nawaz MOHAMUDALLY, Trend Analyses of Parameters of Equations for Energy Consumption Ratio Achievable in Ubicomp MANET Using Location-Aware Transmission, ACCN 2017.

[35] M. Kaleem GALAMALI, Assoc. Prof Nawaz MOHAMUDALLY, Trend Analyses of Parameters of Equations for Minimum Energy Consumption Ratio Achievable in Ubicomp MANETs Using Location-Aware Transmission, ACCN 2017.

[36] M. Kaleem GALAMALI, Assoc. Prof Nawaz MOHAMUDALLY, Trend Analyses of Parameters of Equations for Maximum Energy Consumption Ratio Achievable in Ubicomp MANETs Using Location-Aware Transmission, ACCN 2017.

[37] M. Kaleem GALAMALI, Assoc. Prof Nawaz MOHAMUDALLY, Trend Analyses of Parameters of Equations for Overall Fairness Ratio Achievable in Ubicomp MANETs Using Location-Aware Transmission, ACCN 2017.

[38] M. Kaleem GALAMALI, Assoc. Prof Nawaz MOHAMUDALLY, Trend Analyses of Parameters of Equations for Energy Consumption Fairness Proportion Achievable in Ubicomp MANETs Using Location-Aware Transmission, CEET 2017

[39] M. Kaleem GALAMALI, Assoc. Prof Nawaz MOHAMUDALLY, Trend Analyses of Parameters of Equations for Minimum Fairness Proportion Achievable in Ubicomp MANETs Using Location-Aware Transmission, CEET 2017

[40] M. Kaleem GALAMALI, Assoc. Prof Nawaz MOHAMUDALLY, Trend Analyses of Parameters of Equations for Maximum Fairness Proportion Achievable in Ubicomp MANETs Using Location-Aware Transmission, CEET 2017

[41] M. Kaleem GALAMALI, Assoc. Prof Nawaz MOHAMUDALLY, Trend Analyses of Parameters of Equations for Sender Fairness Proportion Achievable in Ubicomp MANETs Using Location-Aware Transmission, CEET 2017

[42] M. Kaleem GALAMALI, Assoc. Prof Nawaz MOHAMUDALLY, Trend Analyses of Parameters of Equations for Packets Per Distance Achievable in Ubicomp MANETs Using Location-Aware Transmission, CEET 2017

[43] M. Kaleem GALAMALI, Assoc. Prof Nawaz MOHAMUDALLY, Trend Analyses of Parameters of Equations for Maximum CBR Distance Achievable in Ubicomp MANETs Using Location-Aware Transmission, CEET 2017

[44] M. Kaleem GALAMALI, Assoc. Prof Nawaz MOHAMUDALLY, Trend Analyses of Parameters of
Equations for Minimum CBR Distance Achievable in Ubicomp MANETs Using Location-Aware Transmission, CEET 2017

[45] M. Kaleem GALAMALI, Assoc. Prof Nawaz MOHAMUDALLY, Trend Analyses of Parameters of Equations for Range CBR Distance Achievable in Ubicomp MANETs Using Location-Aware Transmission, CEET 2017

[46] M. Kaleem GALAMALI, Assoc. Prof Nawaz MOHAMUDALLY, Trend Analyses of Critical Values Obtained for Sender Node Energy Savings Achievable in Ubicomp MANETs Using Location-Aware Transmission, CEET 2017

[47] M. Kaleem GALAMALI, Assoc. Prof Nawaz MOHAMUDALLY, Trend Analyses of Critical Values Obtained for Overall Node Energy Savings Achievable in Ubicomp MANETs Using Location-Aware Transmission, CEET 2017

[48] M. Kaleem GALAMALI, Assoc. Prof Nawaz MOHAMUDALLY, Trend Analyses of Critical Values Obtained for Sender Node Extra Energy Savings Achievable in Ubicomp MANET Against Direct Node-to-Node LocationAware Transmission, CEET 2017

[49] M. Kaleem GALAMALI, Assoc. Prof Nawaz MOHAMUDALLY, Trend Analyses of Critical Values Obtained for Overall Nodes Extra Energy Savings Achievable in Ubicomp MANET Against Direct Node-to-Node LocationAware Transmission, CEET 2017

[50] M. Kaleem GALAMALI, Assoc. Prof Nawaz MOHAMUDALLY, Trend Analyses of Critical Values Obtaine for Energy Consumption Ratio Achievable in Ubicomp MANETs Using Location-Aware Transmission Strategies, CEET 2017

[51] M. Kaleem GALAMALI, Assoc. Prof Nawaz MOHAMUDALLY, Trend Analyses of Critical Values Obtained for Minimum Energy Consumption Ratio Achievable in Ubicomp MANETs Using Location-Aware Transmission Strategies, CEET 2017

[52] M. Kaleem GALAMALI, Assoc. Prof Nawaz MOHAMUDALLY, Trend Analyses of Critical Values Obtained for Maximum Energy Consumption Ratio Achievable in Ubicomp MANETs Using Location-Aware Transmission Strategies, CEET 2017

[53] M. Kaleem GALAMALI, Assoc. Prof Nawaz MOHAMUDALLY, Trend Analyses of Critical Values Obtained for Overall Fairness Ratio Achievable in Ubicomp MANETs Using Location-Aware Transmission Strategies, CEET 2017

[54] M. Kaleem GALAMALI, Assoc. Prof Nawaz MOHAMUDALLY, Trend Analyses of Critical Values Obtained for Energy Consumption Fairness Proportion Achievable in Ubicomp MANETs Using Location-Aware Transmission Strategies, ACCN 2017.

[55] M. Kaleem GALAMALI, Assoc. Prof Nawaz MOHAMUDALLY, Trend Analyses of Critical Values Obtained for Minimum Fairness Proportion Achievable in Ubicomp MANETs Using Location-Aware Transmission Strategies, ACCN 2017.

[56] M. Kaleem GALAMALI, Assoc. Prof Nawaz MOHAMUDALLY, Trend Analyses of Critical Values Obtained for Maximum Fairness Proportion Achievable in Ubicomp MANETs Using Location-Aware Transmission Strategies, ACCN 2017.

[57] M. Kaleem GALAMALI, Assoc. Prof Nawaz MOHAMUDALLY, Trend Analyses of Critical Values Obtained for Sender Fairness Proportion Achievable in Ubicomp MANETs Using Location-Aware Transmission Strategies, ACCN 2017.

[58] M. Kaleem GALAMALI, Assoc. Prof Nawaz MOHAMUDALLY, Trend Analyses of Critical Values Obtained for Packets Per Distance Achievable in Ubicomp MANETs Using Location-Aware Transmission Strategies, ACCN 2017.

[59] M Kaleem GALAMALI Assoc. Prof Nawaz MOHAMUDALLY, Trend Analyses of Critical Values Obtained for Maximum CBR Distance Achievable in Ubicomp MANETs Using Location-Aware Transmission Strategies, ACCN 2017.

[60] M. Kaleem GALAMALI, Assoc. Prof Nawaz MOHAMUDALLY, Trend Analyses of Critical Values Obtained for Minimum CBR Distance Achievable in Ubicomp MANETs Using Location-Aware Transmission Strategies, ACCN 2017.

[61] M. Kaleem GALAMALI, Assoc. Prof Nawaz MOHAMUDALLY, Trend Analyses of Critical Values Obtained for Range CBR Distance Achievable in Ubicomp 
MANETs Using Location-Aware Transmission Strategies, ACCN 2017.

[62] M. Kaleem GALAMALI, Assoc. Prof Nawaz MOHAMUDALLY, Extending Sender Node Battery Availability in Ubicomp with Location-Aware MANET Transmission, ACCN 2017.

[63] M. Kaleem GALAMALI, Assoc. Prof Nawaz MOHAMUDALLY, Extending Overall Node Battery Availability in Ubicomp with Location-Aware MANET Transmission, ACCN 2017.

[64] M. Kaleem GALAMALI, Assoc. Prof Nawaz MOHAMUDALLY, Extension of Sender Node Battery Extra Availability in Ubicomp with Location-Aware MANET Transmission Compared to Direct Node-To-Node Transmission, ACCN 2017.

[65] M. Kaleem GALAMALI, Assoc. Prof Nawaz MOHAMUDALLY, Extension of Overall Node Battery Extra Availability in Ubicomp with Location-Aware MANET Transmission Compared to Direct Node-To-Node Transmission, ACCN 2017.

[66] Mohammed Humayun Kabir, Syful Islam, Md. Javed Hossain, Sazzad Hossain, Detail Comparison of Network Simulators, International Journal of Scientific \& Engineering Research, Volume 5, Issue 10, October-2014

[67] Arun Gupta, Web site blog "http://arungupta.co.in/blog/?p=37", title "segmentation fault in NS-2, $24^{\text {th }}$ June 2012, accessed on $13^{\text {th }}$ March 2014

About Author (s):

Associate Professor Nawaz Mohamudally works at University of Technology, Mauritius (UTM) and has undertaken supervision of MPhil/PhD Students for many years.

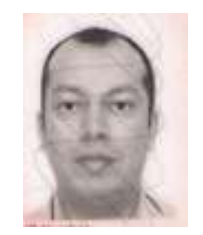

M. Kaleem Galamali is a part-time student (achieved M Phil Transfer on 28.10.2014, currently PhD student) at UTM under supervision of A.P. Nawaz Mohamudally. 